\title{
Strategy on the National Unity and Politics Agency (KESBANGPOL) in Maintaining Ethnicity and Religious Relations Based on Huma Betang Philosophy in Central Kalimantan
}

\author{
Suprayitno $^{1}$, Triyani $^{2}$, Putri Fransiska Purnama Pratiwi ${ }^{3}$ \\ ${ }^{I}$ Department of Public Administration, Faculty of Social and Political Sciences, University of Palangka Raya, \\ Indonesia \\ ${ }^{2}$ Pancasila and Citizenship Education Study Program, Faculty of Teacher Training and Education, University \\ of Palangka Raya \\ ${ }^{3}$ Legal Studies Program at the Faculty of Law, University of Palangka Raya \\ suprayitno@fisip.upr.ac.id
}

\begin{abstract}
The population in Central Kalimantan is plural, both in terms of ethnicity and religion. The indigenous people are Dayaks, but other ethnic groups also live side by side and become part of the people of Central Kalimantan such as Banjar, Javanese, Bugis, Madurese, Batak, Chinese, and so on. Those ethnics currently live in Central Kalimantan. Also, the followers of the religion, such as Muslims, Christians, Catholics, Hindus, Buddhists, and Kaharingan are developing rapidly in Central Kalimantan. The plurality of ethnicity relations has the potential for conflict because the differences in tradition and culture become cultural boundaries which become boundaries among the communities. In 2001 ago, Central Kalimantan Province had experienced a dark period of riots under the ethnicity reason in Sampit, Kotawaringin Timur Regency. The National Unity, Politics and Community Protection Agency (Kesbangpol) is an office in Central Kalimantan Province which the main task is the development of the values of nationalism and conflict management. Then, the particular study aims to analyze the strategies of Kesbangpol in maintaining harmony among religious \& ethnic groups in Central Kalimantan based on Huma Betang Philosophy.
\end{abstract}

Keywords: Harmony; multiculturalism; huma betang philosophy.

\section{Introduction}

Indonesia is a multicultural country that has extraordinary socio-cultural wealth. At the real level, Hikam explained that the Indonesian people were not only Bhinneka (diversity) in ethnicity, religion, culture, and race, but also the level of cultural evolution which are from simple societies to complex societies (Hikam M.A.S, 2000). In social life, diversity becomes a symbiotic relationship of mutualism among components of society, especially as a social structure. However, diversity might change into potential conflicts, especially among the elements of multiculturalism.

Conflict factors can start from differences in identity to the struggle to fulfill the interests and needs of each (Suharno, 2012). Materially, inter-religious harmony in Central Kalimantan Province is very expensive; therefore, all elements of government and society must work together to maintain this diversity by upholding tolerance. Based on data from the Central Statistics Agency (BPS) in 2018, the number of Muslims is 1,944,177, Protestant is 420,624, Catholic is 86,238, Hinduism is 218,890, and Buddhism is 9,388 (BPS, 2017). Also, this province is heterogeneous in terms of ethnicity. The population on ethnicity are; Dayaks of 742,729 people or $41.24 \%$ (consisting of $18.2 \%$ Dayak Ngaju, 9.57\% Dayak Sampit, 7.51\% Dayak Bakumpai, 3.34\% Dayak Katingan and 2.8\% Dayak Ma'anyan), Banjar of 435,756 people or $24.2 \%$, Javanese of 325,160 people or $18.06 \%$, Madurese of 62,228 people or $3.46 \%$, Sundanese of 24,479 or $1.36 \%$, and the rest are the tribe of Bugis, Betawi, 
Minangkabau, and Banten (Cahyoko. H, 2008).

Having the title as a province with a high level of tolerance, it does not necessarily make the Central Kalimantan Province zero case from conflict. A series of conflicts and riotsreligious based have occurred in Central Kalimantan. The National Unity and Politics Agency (Kesbangpol) Central Kalimantan Province published eight data of potential vulnerability to horizontal conflicts leading to SARA (Ethnic, Religion, and Race) conflicts in Central Kalimantan. The eight factors are ethnicity, company land disputes with the community, land disputes among communities, mining, regional head elections (PILKADA), the issue of regional spatial plans, and forest fires (Herdi, C, 2017).

The province of Central Kalimantan has a dark history of bloody conflicts between Dayaks and Madurese in 2001. Many factors arise behind this bloody conflict. Ethnicity and religion relation always attach to bloody conflict. Over time, the people of Central Kalimantan have a good adaptation strategy in the context of conflict resolution. In maintaining ethnicity relation in Central Kalimantan, local wisdom is needed that the values used at the level of praxis. The people of Central Kalimantan uphold the philosophy of Huma Betang which is full of communalism values.

The Huma Betang philosophy is a subjective reality of the life of the Dayak community which contains the values of togetherness, help, egalitarianism, kinship, consensus and living in a society. The high of cultural values contained in the Huma Betang philosophy might use as a reference or orientation for policymakers, especially Kesbangpol in maintaining the dynamics of inter-ethnic relations and adaptation strategies to build harmony in Central Kalimantan. Therefore, the particular study tries to discuss and analyze further the "Strategy of the National Unity and Politics Agency (KESBANGPOL) in Maintaining Ethnic and Religious Relations Based on the Philosophy of Huma Betang in Central Kalimantan Province.

\section{Review of Literature}

The strategy may define as "the art of the general" or the art used by a commander in battle (Sumarsono, 2001). According to J. David Hunger and Thomas L. Wheelen in Nugroho (2010: 41), the strategy is a formulation of comprehensive planning about how an organization achieves its mission and objectives. Salusu stated a strategy as art using the skills and resources of an organization to achieve its goals through effective relations with the environment under favorable conditions (Salusu, 2006).

An organization must concern the way the organization is led by a leader or commonly called as strategic management. Strategy management is the art of knowledge in formulating, implementing and evaluating the cross-functional decisions with the aim to achieve the determined goals (David F.R, 2009). Strategy management is a series of activities carried out by organizational leaders to achieve organizational goals by formulating some decisions and following by evaluation. Organizational management occupies an important position to make the organization is more productive because the strategy contains clear planning and direction.

In short, the strategy is a plan or step made by the decision-maker to achieve the desired goals or solve a problem through formulations of solving for short-term or long-term. A strategy contains tips, ways, and tactics prepared systematically and comprehensively to achieve the goals and consist of the ways to create effective relations between organizational 
resources with the environment both inside and outside the organization.

In this research, Kesbangpol strategy in maintaining ethnicity-relations means an effort or ways of the Kesbangpol agency that focuses on the objectives both long and short-term along with the preparation of ways or efforts to achieve the goals. Concerning the inter-ethnic relations in Central Kalimantan, surely, raises a condition, called as cohesion and segregation. The condition is normal in a society with a plural cultural background.

Ethnic relation is part of the social structure of society in which consists of various complex social interactions. Of course, in establishing the social interaction in a plural society involves various elements of ethnicity identity. In short, this study aims to explore the Kesbangpol strategy in maintaining ethnicity relations in Central Kalimantan Province.

The particular research used several theoretical frameworks analysis blades, such as structural functionalism theory. Society is seen as a unifying element that integrated into one unit and has a different function but interrelated functions, as well as creates social consensus and order to adapt both internal and external changes. Based on Durkheim's analysis, the roots of structural functionalism theory emphasize the aspects of integration and solidarity (collective awareness) in society. The concept of social integration explains the various elements of society maintain unity and integrated one with another.

Social integration refers to a situation where all elements in society are interconnected one another. Society is a complex system in various needs and creates space in social integration for the survival of the community itself. Social integration will birth through social solidarity. Social solidarity is a crucial concept in heterogeneous societies either religious-based or ethnicity-based. But, in a pluralistic society, social integration might not be achieved perfectly, but dynamically moves towards equilibrium. There are potential for friction or conflict between components of society in a sociologically heterogeneous society. However, the situation can be overcome within a certain time through the process of adaptation and institutionalization. Thus, changing in society might see as a process of adaptation supported by a process of differentiation and innovation combined with values that develop and highly esteem held by the community.

Another important theory is the theory of social identity and adaptation strategies. Social identity is part of a person's self-concept based on identification under nation, ethnic group, gender or other social affiliation. Social identity provides strong legitimacy that the community has a place and position in the world, and recognition from other parties to create social equality (Haryanto J.T, 2013). Social identity, Jenkin defined as a concept of a person or group of people knows each other. Individual and collective identities develop systematically and involve one another. Thus, social identity is a characteristic that distinguishes from other groups. In this case, it might be ethnicity identity which establishes based on social, cultural, traditional, cultural or linguistic differences. Each ethnic group has own social identity and adaptation strategies. Gudykunts and Kim, adaptation occurs especially in terms of interacting with different environments and cultures. The ability of individuals to communicate following normal and local cultural values depends on the adaptation process. There are several important factors in carrying adaptation strategies, namely the power of openness and the ability of positive thinking. An important key in making adaptations is either migrant people or people of local cultural accepting each other's culture. The definition of adaptation is oriented to an effort of humans in obtaining their desires or adapts their lives need to the environment (Jamil M.M, 2012). 


\section{Methodology}

The particular research used a qualitative approach. Historically, Central Kalimantan had experienced a bloody conflict between ethnic Dayaks and Madurese in 2001. Thus, the particular research discussed and analyzed the Kesbangpol strategy in maintaining ethnic relations in Central Kalimantan with the aim to maintain harmony.

Data collection techniques were an interview, observation, and documentation. The interview aimed to explore the Kesbangpol strategy in maintaining ethnic relations in Central Kalimantan with the aim to maintain the harmony and explore aspects related to the issue. Observation technique carried out to see directly the life and ethnic social interaction in Central Kalimantan province.

Observation carried out through activities of Kesbangpol, especially concerning maintain the ethnic relations in Central Kalimantan and following activities of indigenous peoples, especially activities related to traditional traditions and religious rituals.

Document review carried out to obtain information from written documents, such reports from government board and local regulations issued by regional governments relevant to this research.

\section{Result and Discussion}

\subsection{The Huma Betang Philosophy as the Foundation for Creating Harmony in Central Kalimantan Province}

Indonesia is a country that recognizes custom, including custom applies in Central Kalimantan province, namely the philosophy of Huma Betang, which applies sociologically to the community and applies legally through the provincial regulation of Central Kalimantan Number 10 of 2010 concerning Amendments to the Provincial Regulation of Central Kalimantan Number 16 of 2008 concerning the Dayak Customary Institution in Central Kalimantan province. Customs or habits (tradition) among the Dayak community and apply based on the life experience of the Dayak community, establish the norms or behavior with the philosophy of Huma Betang.

Huma Betang is a typical traditional house inhabited by the Dayak people, especially in the upstream river area which is usually the center of the Dayak tribe of Central Kalimantan. In principle, there are many aspects underlie the Huma Betang philosophy, especially in the Dayak Ngaju community. Betang culture is a reflection of togetherness in the daily lives of people of Central Kalimantan. In this Betang House (Long House), every individual in the household and community is systematically regulated through the mutual agreement as wrote into customary law. Indonesia recognizes the customs that live among society in Indonesia, including the customs of the philosophy of Huma Betang (philosophical) in Central Kalimantan. It applies sociologically in the community and also applies based on the life experience of the Dayak people which establish norms or rules of behavior with the philosophy of Huma Betang. The philosophy rules the communities' lives of the Dayak tribe. Also, it is a view of life connected with the philosophy of Pancasila (Five Pillars) as a view of life as a nation and state (Ibnu Elmi, 2018).

The values contained in Huma Betang are highly valued by the people of Central Kalimantan. These values are upholding peace and non-violence and a life of high tolerance among religious communities. Specifically, the values contained in Huma Betang consist of 
four pillars namely togetherness, honesty, equality, and mutual respect (tolerance). The four pillars in Huma Betang are;

a. The value of togetherness is mutual cooperation. For example, in maintaining and applying Huma Betang and farming of planting rice.

b. The value of honesty is a good attitude which means there is no lie or, in other words, telling the truth to others since from small thing to big things.

c. The value of equality is an attitude in terms of equality with one another. For example, people have the same rights and obligations of one another in Huma Betang (Long House).

d. Tolerance is an attitude of respecting differences or backgrounds of others. For example, respect people who have different religions in Huma Betang (Long House).

The values of Huma Betang are seen in the philosophy of Belom Bahadat and the spirit of Isen Mulang. Belom Bahadat is a value strongly held by the people of Central Kalimantan to practice the values of cultural customs in daily life. Besides functioning as a traditional house, explained by Ibnu Elmi AS Pelu \& Jefry Tarantang (Ibnu Elmi, 2018), Huma Betang has a very deep and fundamental philosophy of life for the Dayak community. The philosophies of Huma Betang are:

a. Living in Harmony and Peace in Differences

A large family consisting of various religions and beliefs live together in Huma Betang or long house, but they always live in harmony and peace. The differences are never used as a means of dividing them. Along with the development of the times, the Dayak people have begun to leave their traditional homes and move to modern home. However, harmony does not only occur at Huma Betang. All the people of Central Kalimantan always maintain harmony through mutual respect and mutual tolerance.

b. Mutual Cooperation

The differences among society in Central Kalimantan do not make people who live in Huma Betang think only their groups. They work hand in hand in working without concerning the ethnicity, religion, race or class.

c. Settling Disputes with Peace and Family-based method

In principle, every people who live in Huma Betang want peace and kinship. When disputes occur, they are settled in a peaceful manner and have a high sense of kinship. Dark riots in the past are bloody riots in Sampit between the Dayak and Madura tribes. The riots that occur make this province unsafe, fight and brutality are in everywhere and sadistic slaughter also occurred. This riot has become a valuable lesson that caring for diversity and upholding tolerance is a need for a pluralistic society.

Widjono in Suwarno (2017) stated the views of the Dayak community concerning Huma Betang reflected in the following aspects.

First are the residential aspects (people who live in Huma Betang). Betang house (Long House) is a permanent multi-family structure and has functioned as the main residence next to the cottage house in the rice field. Second are aspects of law and property rights. Long house has a clear ownership aspect. In particular, the ownership rights of all families together control and own all land in Betang area. The right to long house is secondary, while the primary right is held by each family or small family group that bound by kinship. Long House is a very important judicial unit. A dispute often solves in long house internally by elders. The prominent values are the authority of a person or relatively small of a certain family. Also, the more important is the authority of the long house as a whole. This is caused by a strong egalitarianism style in Dayak society. Third is the economic aspect. Long house 
plays an important role in the distribution of labor flows and works among families. The use of additional labor from other families is the key to the farming system.

According to Laksono (2016), Betang culture is a metaphor for togetherness in the daily life of Dayaks who used to live in long houses. Every individual's life in the household and community is systematically regulated through the mutual agreement as wrote in customary law. The prominent value in life in the long house is the value of togetherness (communalism) among the people who live in it, regardless of the differences.

The philosophy of Huma Betang is the values that will always be held in high esteem by the people of Central Kalimantan. This implies that the values in Huma Betang are not just mere inheritance, but valuable assets must be managed by the people of Central Kalimantan to deal with increasingly surging currents of globalization and modernization. Through the approach of local wisdom of Huma Betang culture concerns the issue of intrinsic value that lives and is maintained by the people of Central Kalimantan. Huma Betang is a pidgin of culture which wrote in Provincial Regulation of Central Kalimantan Number 10 of 2010 concerning Amendment to the Provincial Regulation of Central Kalimantan Number 16 of 2008 concerning Dayak Customary Institutions of Central Kalimantan is a living behavior that upholds honesty, equality, togetherness and tolerance and obedience to the law. The philosophy of Huma Betang in Central Kalimantan is togetherness in diversity which means having a spirit of unity, ethos, work and high tolerance to manage together the differences and honest competing. So, there will be no gap that separates, as well as destroys.

The Dayak community also has a shared attitude that is shown by people who live it, regardless of the differences they have. Togetherness also has the meaning as equality with the proverb of duduk sama rendah berdiri sama tinggi (A dwarf is on a giant's shoulder can see of the two). The togetherness among individuals who have different characters is beautiful and seems difficult to realize, but this found in Huma Betang. In life, the Dayak people who live in Huma Betang maintain the value of honesty. Being honest is telling the truth, not stealing, cheating or lying in any way. On the other hand, Huma Betang also contains a tolerance value. The differences in the Betang Huma required high tolerance to avoid a dispute or conflict. With the differences among individuals become a support factor and complement each other. Tolerance is important in the midst of differences due to tolerance creates peace.

The people of Central Kalimantan uphold the Huma Betang culture. And, this culture is deeply rooted in the lives of the people of Central Kalimantan. The meaning of Betang Huma culture is communalism, which contains togetherness values, mutual help, egalitarian, kinship, consensus, and civilized life. Communalism is the social construction of the people of Central Kalimantan and used to bound social interaction (Suwarno, 2017).

\subsection{The strategy of Kesbangpol in maintain the Ethnicity and Religion Relations in Central Kalimantan}

Indonesia is a country founded on diversity. Various cultural characteristics, ethnicity, religion, and races together play a role as pillars of this nation. The key to the state is determined by the cohesiveness of the elements among the pillar. While the inter-ethnic group relations are a problem that often colors the life journey of the nation. In this context, inter-ethnic group relations do not always run well. History has recorded a number of tragedies caused by inter-ethnic relations.

Ethnicity is a group of people who share a common history, ancestors, origins, and 
language that are reflected in distinctive symbols such as religion, cloth, and tradition. In short, ethnicity means a group of people who are culturally different from other groups. A nation and country may have ethnic diversity, each of which has a prominent characteristic and easily be distinguished from other ethnic groups.

The big problem along the journey of the Indonesian people is ethnic conflict. Indonesia is a country with a multicultural community background. Ethnicity is a mosaic of the Indonesian people united by a common struggle against the invaders (Agung Prabowo S.F, 2014).

Factors trigger inter-ethnic conflict grouped into two, namely (1) cultural paradigm and (2) structural paradigm (Darity JR Wiliam, 2005). The cultural paradigm views ethnicity conflict as an issue of social identity caused by threats to ethnicity culture. This threat might trigger by ethnocentrism. Structural paradigm views ethnic conflict is not an issue of ethnic identity, but rather an issue closely related to economic problems, political problems, including settlement problems. Structural inter-ethnic conflict is triggered by three main factors, namely (1) the struggle for scarce resources, such as power struggles, employment, territorial, economic, and recognition of rights, (2) modernization is contrary to ethnic culture, and (3) addition of ethnic members through non-kinship mechanisms. Also, there are other triggering factors, such as (1) the cultural similarity of an ethnic group that ignores social equality, (2) triggering of bitterness and injustice experienced in the past by an ethnic group, (3) the triggering of bad personal experiences of an ethnic group, (4) and the simplification of social complexity into simple contradictions (Ratcliffe, P. 2006).

The people in Central Kalimantan province classified as heterogeneous among the aspects of religious, cultural and community. Based on data from the Central Statistics Agency (BPS) in 2018, the number of Muslims is 1,944,177, Protestant is 420,624, Catholic is 86,238 , Hinduism is 218,890 , and Buddhism is 9,388 (https://kalteng.bps.go.id). Also, this province is heterogeneous in terms of ethnicity. The population on ethnicity are; Dayaks of 742,729 people or 41.24\% (consisting of 18.2\% Dayak Ngaju, 9.57\% Dayak Sampit, 7.51\% Dayak Bakumpai, 3.34\% Dayak Katingan and 2.8\% Dayak Ma'anyan), Banjar of 435,756 people or $24.2 \%$, Javanese of 325,160 people or $18.06 \%$, Madurese of 62,228 people or $3.46 \%$, Sundanese of 24,479 or $1.36 \%$, and the rest are the tribe of Bugis, Betawi, Minangkabau, and Banten (Cahyono. H 2008).

Having the title as a province with a high level of tolerance, it does not necessarily make the Central Kalimantan Province zero case from conflict. A series of conflicts and riotsreligious based have occurred in Central Kalimantan. The National Unity and Politics Agency (Kesbangpol) Central Kalimantan Province published eight data of potential vulnerability to horizontal conflicts leading to SARA (Ethnic, Religion, and Race) conflicts in Central Kalimantan. The eight factors are ethnicity, company land disputes with the community, land disputes among communities, mining, regional head elections (PILKADA), the issue of regional spatial plans, and forest fires (Herdi C, 2017).

The province of Central Kalimantan has a dark history of bloody conflicts between Dayaks and Madurese in 2001. Many factors arise behind this bloody conflict. Ethnicity and religion relation always attach to bloody conflict. Over time, the people of Central Kalimantan have a good adaptation strategy in the context of conflict resolution. In maintaining ethnicity relation in Central Kalimantan, local wisdom is needed that the values used at the level of praxis. The people of Central Kalimantan uphold the philosophy of Huma Betang which is full of communalism values. 
The Huma Betang philosophy is a subjective reality of the life of the Dayak community which contains the values of togetherness, help, egalitarianism, kinship, consensus and living in a society. The high of cultural values contained in the Huma Betang philosophy might use as a reference or orientation for policymakers, especially Kesbangpol in maintaining the dynamics of inter-ethnic relations and adaptation strategies to build harmony in Central Kalimantan.

In practice, Kesbangpol has an important position in caring and maintaining diversity in Central Kalimantan Province due to the reality of multicultural people in this province. In performing its duties, Kesbangpol has very strategic vision and mission to embrace the people of Central Kalimantan in a family frame. The vision and mission of the Kesbangpol Central Kalimantan Province are.

Table 1. Data of Mass Organization from National Unity and Politics Agency of Central Kalimantan until 11 June 2019

\begin{tabular}{|c|l|c|}
\hline No. & \multicolumn{1}{|c|}{ Description } & Total \\
\hline 1. & $\begin{array}{l}\text { Registered mass organization on Kesbangpol of the } \\
\text { Central Kalimantan Province until January 2019 }\end{array}$ & 599 \\
\hline 2. & Mass organization declare disbandment & 6 \\
\hline 3. & Revoked SKT (frozen) & 94 \\
\hline 4. & Active SKT & $\begin{array}{l}\text { Mass organization with deactivate SKT (SKT } \\
\text { issued until 2013) } \\
\text { a. a. Mass organization declare disbandment: 6 } \\
\text { Mass Organizations } \\
\text { b. Revoked / frozen organizations: 2 Mass } \\
\text { Organizations } \\
\text { c. Mass Organizations with expired SKT: 447 } \\
\text { Mass Organizations }\end{array}$ \\
\hline 6. & $\begin{array}{l}\text { Legal / tiered mass organization that report the } \\
\text { management at the provincial level }\end{array}$ & 505 \\
\hline 7. & $\begin{array}{l}\text { Mass organization with special concerning form the } \\
\text { Ministry of Home Affairs }\end{array}$ & 45 \\
\hline 8. & $\begin{array}{l}\text { Mass organization with special concerning form the } \\
\text { Provincial Government of Central Kalimantan }\end{array}$ & 5 \\
\hline
\end{tabular}

(Source: Resilience, Economy, Social Culture and Community Organizations, Kesbangpol of Central Kalimantan).

\subsection{Inhibiting Factors Found by Kesbangpol of Central Kalimantan Province in Maintaining Ethnicity Relations}

In conducting their duties, Kesbangpol of Central Kalimantan Province found several obstacles. Mr. Agus Pramono, the Head of Kesbangpol of the Central Kalimantan Province, said that the limited funds might be identified as the first factor that makes un-optimal action in fostering mass organizations in Central Kalimantan. Because, by the limited funds, also limited fostering activities for the mass organization.

Moreover, Mr. Matius, the Head of Social, Cultural and Mass Organizations stated that 
many organizations seldom reported their annual activities to Kesbangpol. As a result, he said, they found difficulties to monitor the activities of the organizations. Other factors, Mr. Rodi, head of Ideology Resilience and National Insights, stated that Central Kalimantan has a large demographic area and limited means and infrastructure making the monitoring activities of mass organizations and religious organizations in the regions is not yet optimal.

And the last, the inhibiting factor also stated by the Head of Kesbangpol of Central Kalimantan Province, Mr. Agus Pramono stated that there is no Integrated Team of the Central Kalimantan Provincial Government related to the supervision of mass organizations and religious organizations in Central Kalimantan. He hopes, there will be a special team under the Regional Secretary related to the development of the mass organization. Then, there will be more institutions/services that will strengthen and support the coordination and communication in creating harmony in Central Kalimantan province.

\section{Conclusion}

In maintaining ethnicity relations in Central Kalimantan province, Kesbangpol of Central Kalimantan Province has a comprehensive and systematic strategy with the aim to maintain harmony in Central Kalimantan province. The action taken by Kesbangpol of the Central Kalimantan Province is through monitoring the activities of mass organizations, youth organizations, and religious organizations in Central Kalimantan Province. Besides that, it also increases the role of mass organization, youth organization, and religious organizations in early anticipation and alerts the emergence of the things that threaten the harmony and peace. Here, Kesbangpol of Central Kalimantan province has built several forums including the FKUB, Forum Bela Negara and Forum Pembauran Kebangsaan.

The inhibiting factors found by Kesbangpol of Central Kalimantan province in maintaining ethnicity and religious relations in Central Kalimantan are:

a. Budget limitation causes the limited programs arranged by the Kesbangpol.

b. The large demographic area of Central Kalimantan province and limited facilities and infrastructure makes un-maximal monitoring activities to the mass organizations and religious organizations in the regions.

c. Mass and Religious organizations seldom report their activities to the Kesbangpol of Central Kalimantan Province.

d. Need an integrated team from the Provincial Government of the Central Kalimantan province related to the monitoring of mass organizations and religious organizations.

\section{References}

Agung Prabowo, S. F. (2014). Kecemasan Komunikasi Dalam Relasi antar Etnik . Jurnal Ilmu Komunikasi, Vol 13, No 3, pp. 231-242

BPS. (2017). Jumlah pemeluk agama menurut kabupaten/kota di Kalimantan Tengah. Palangka Raya: BPS Kalimantan Tengah. Accessed 18 August 2018 on this link: https://kalteng.bps.go.id/statictable/2017/11/01/592/jumlah-pemeluk-agama-menurutkabupaten-kota-di-provinsi-kalimantan-tengah-2016.html.

Cahyono, H. Dkk. (2008). Konflik Kalbar dan Kalteng Jalan Panjang Meretas Perdamaian. Yogyakarta: P2P-LIPI bekerjasama dengan Pustaka Pelajar.

Darity Jr., William A. (Ed.). (2005). International Encyclopedia of the Social Sciences. 
2ned. Volume 3. New York: Macmillan Reference.

David, F. R. (2009). Manajemen strategis. Jakarta: Salemba Empat.

Haryanto, J.T. Dinamika kerukunan intern umat islam dalam relasi etnisitas dan agama di Kalteng. Jurnal Analisa, 20 (01), pp 13-24.

Herdi, C. (2017). Ini delapan isu yang bisa memicu konflik sara di Kalteng. Accessed August 18, 2018 on this link: https://www.borneonews.co.id/berita/51374-ini-delapanisu-yang-bisa-memicu-konflik-sara-di-kalteng.

Hikam, M.A.S. (2000). Islam, demokratisasi dan pemberdayaan civil society. Jakarta: Airlangga.

Ibnu Elmi AS Pelua, J. T. (2018). Interkoneksi Nilai-Nilai Huma Betang Kalimantan Tengah dengan Pancasila . Jurnal Studi Agama dan Masyarakat, Vol. 14, No 02 pp. 119-126.

Jamil, M. M. (2012). Dinamika identitas dan strategi adaptasi minoritas syi'ah di Jepara. Program Doktor Pascasarjana IAIN Walisongo Semarang.

Kriyantono. R. (2006). Teknik Praktis Riset Komunikasi. Jakarta : Kencana Prenada Media Group.

Moleong. L.J. (1998). Metodologi penelitian kualitatif. Bandung: Remaja Rosdakarya.

Okta H. N. (2018). Pendidikan Multikultural di Indonesia: Analisis Sinkronis dan Diakronis. Jurnal Pendidikan, Sosiologi dan Antropologi. Volume 2, Nomor 1, Maret 2018. pp. 105-115.

P.M. Laksono, dkk., (eds.), (2006). Pergulatan Identitas Dayak dan Indonesia: Belajar dari Tjilik Riwut, Yogyakarta: Galangpress.

Ratcliffe, P. (2006). Conceptualizing "Race", Ethnicity and Nation: Towards a Comparative Perspective in Ratcliffe, P. (Ed). Race, Ethnicity and Nation. London: Taylor \& Francise.

Salusu, J. (2006). Pengambilan keputusan stratejik untuk organisasi publik dan organisasi non profit. Jakarta: Grasindo.

Suharno. (2012). Resolusi konflik sosial dari ruang kelas dan vernakularisasi. (Makalah Disampaikan dalam Diskusi Umum Fakultas Ilmu Sosial UNY Bekerjasama dengan Harian Kedaulatan Rakyat Yogyakarta, June 14, 2012 in Ki Hajar Dewantara FIS UNY).

Sumarsono, S. et.al. (2001). Pendidikan Kewarganegaraan. Jakarta: PT Gramedia Pustaka Utama.

Suwarno. (2017). Budaya Huma Betang Masyarakat Dayak Kalimantan Tengah Dalam Globalisasi: Telaah Konstruksi Sosial. LINGUA, Vol. 14, No. 1, pp. 89-102.

Wade, C \& Tavris C. (2009). Psikolog (10 ${ }^{\text {th }}$ ed.). Jakarta: Erlangga. 